\title{
COMPARISON OF PHOTOSYNTHETIC PARAMETERS IN DIFFERENT WHEAT (TRITICUM AESTIVUM L.) VARIETIES
}

Ilona VAGUSEVIČIENĖ, Institute of Agriculture and Food Science, Faculty of Agronomy, Aleksandras Stulginskis University, Address: Studentų 11, Akademija, Lithuania; i.vaguseviciene@gmail.com (corresponding author)

Sonata KAZLAUSKAITE், Institute of Biology and Plant Biotechnology, Faculty of Agronomy, Aleksandras Stulginskis University, Address: Studentų 11, Akademija, Lithuania; sonata.kazlauskaite@asu.lt

Aiste JUCHNEVIČIENĖ, Institute of Agriculture and Food Science, Faculty of Agronomy, Aleksandras Stulginskis University, Address: Studentų 11, Akademija, Lithuania; aiste.juchneviciene@asu.lt

Asta BYLAITE, Institute of Agriculture and Food Science, Faculty of Agronomy, Aleksandras Stulginskis University, Address: Studentų 11, Akademija, Lithuania

Audrone ŽEBRAUSKIENE், Institute of Agriculture and Food Science, Faculty of Agronomy, Aleksandras Stulginskis University, Address: Studentų 11, Akademija, Lithuania; audrone.zebrauskiene@asu.lt

\begin{abstract}
Dynamics of photosynthesis pigments in the leaves of different varieties of winter wheat during the vegetation period is analyzed in the paper. The accumulation of pigments in the plant depends on the physiological activity, growth and development of the plant, therefore the composition and content of photosynthesis pigments chlorophyll $\mathrm{a}, \mathrm{b}$ and carotenoids reflect the general condition of the plant. The ratio of chlorophyll a / $b$ for normal photosynthesis activity in the leaves of the plant should be at least 1:3. The object of the research is different varieties of winter wheat (Triticum aestivum L.) - 'Artist', 'Edvin', 'Skagen', 'Bertold' and 'Viola'. Field experiment was carried out at the Experimental Station of Aleksandras Stulginskis University in 2015-2016. Soil type was identified as IDg8 - $\mathrm{k}$ (LVg - p - w - cc) - shallow calcareous luvisol (Calc (ar) i - Epihypogleyic Luvisols). Agrochemical parameters of the soil were determined using accepted analytical methods. The content of photosynthesis pigments (chlorophyll a, $\mathrm{b}$ and carotenoids) in green leaf mass was determined in $96 \%$ ethyl alcohol extract applying spectrophotometric Wettstein method, "Genesys" 6 spectrophotometer. The photosynthesis productivity (Fpr) was calculated according to the formula: Fpr $=2(\mathrm{M} 2-\mathrm{M} 1) /(\mathrm{L} 1+\mathrm{L} 2) \mathrm{T}$. The accuracy of the data analysis was estimated according to the standard measurement deviation from the mean. The highest content of photosynthesis pigments has been accumulated by winter wheat variety 'Skagen'. The best result has been observed at the end of nodding stage. A lower content of photosynthesis pigments has been found in the leaves of 'Edvin', 'Viola' and 'Artist' varieties. The highest photosynthesis productivity of all winter wheat varieties has been recorded at the end of nodding stage, and decrease of photosynthesis productivity has been observed since milk maturity stage.
\end{abstract}

Keywords: winter wheat, photosynthesis pigments, varieties.

\section{INTRODUCTION}

The net photosynthetic productivity is one of the most important parameters of photosynthesis. It is expressed by the amount of dry matter content which might be produced of the unit of assimilation area of plant leaves per day (Bluzmanas ir kt., 1991). The effect of environmental factors on plant development and growth is best reflected by the net photosynthetic productivity (Третьяков, 1998).

Observing the net photosynthetic productivity during vegetation different photosynthetic and, at the same time, vital capacity of plants are visible. This parameter is closely related to the amount and relationship of photosynthesis pigments in the leaves. It is closely associated to the amount of nitrogen available to plants in the soil as well (Tranavičienè, 2009).

The relationship between leaf photosynthetic activity, total plant productivity and yield does not always correlate positively, however the overall capacity of the plant's photosynthesis system is an appropriate parameter for selection of genotypes with higher productivity potentials (Balogh et al., 2007; Chapple, Campbell, 2007).

Under changing climatic conditions, not all plant varieties adapt successfully in agroecosystems. Given the fact that winter wheat is recognized as one of the most important nutritional and feed plant among cereals, it is essential to examine the possibilities of their adaptation to climatic conditions. The selection of a plant variety is the first, most basic and most complex stage for winter wheat growers. According to V. Ruzgas and J. Ž. Liatukas (2006), when winter wheat is grown under Lithuanian agro-climatic conditions, it is important that the wheat must be sufficiently freeze tolerant, early maturing, resistant to diseases and to germination inside ears during wet summer. The process of photosynthesis is

Copyright (C) 2017 The Authors. Published by Aleksandras Stulginskis University. This is an open-access article distributed under the terms of the Creative Commons Attribution License (CC-BY 4.0), which permits unrestricted use, distribution, and reproduction in any medium, provided the original author and source are credited. 
performed the most effectively when the optimal amount of photosynthetic pigments exists (Scebba et al., 2003; Sakalauskiene ir kt., 2008; 2009). The amount of chlorophyll in the plant depends on many factors - genetics, growth and developmental processes, environmental conditions, and crop density as well.

Results of the research have shown that about $95 \%$ of the dry matter amount of the plant is produced during the photosynthesis process, which is directly determined by soil productivity and fertilization intensity. For normal photosynthesis, the ratio of chlorophylls in the leaves of poaceous crops must be at least 3:1. Chlorophylls are particularly sensitive to nitrogen variation. Chlorophyll $a$ is less stable than chlorophyll $b$, and therefore, in conditions of unfavourable cultivation or stressors, chlorophyll $a$ content in leaves is significantly reduced and the optimal chlorophyll ratio is affected. Chlorophyll $a$ synthesis might be stimulated by nitrogen fertilization (Beadle et al., 1987).

Exploitation of the photosynthetic productivity of the variety applying balanced fertilization of nitrogen with a maximizing nutrient availability period is one of the ways supporting efficient plant productivity (Tranavičiene், 2009).

The aim of the study was to compare the productivity of photosynthesis of winter wheat varieties ('Artist', 'Edvin', 'Skagen', 'Viola', 'Bertold') during different stages of growth.

\section{MATERIALS AND METHODS}

The experiment was carried out at the Experimental Station of Aleksandras Stulginskis University in 2015-2016. Five winter wheat varieties were examined in the experiment: 'Artist', 'Edvin', 'Skagen', 'Viola', 'Bertold'.The total area of the plot was $40 \mathrm{~m}^{2}(4 \times 10 \mathrm{~m})$, accounting plot $-20 \mathrm{~m}^{2}(2 \times 10 \mathrm{~m})$.

During sowing (on 18th of September in 2015), winter wheat was fertilized with phosphorous, potassium fertilizer $\mathrm{P}_{60} \mathrm{~K}_{60}$. In the spring (on 24th of March and on 29th of April in 2016), after the regeneration of the plant, during tillering stage, the ammonium nitrate $\left(\mathrm{N}_{68+68}\right)$ was given. During jointing stage (on 6th of May in 2016), fertilization through leaves with urea solution $\mathrm{N}_{10}$ was applied. The soil type on the territory of the Experimental Station of Aleksandras Stulginskis University is (Calc(ar)i-Epihypogleyic Luvisols). According to the agrochemical characteristics of the soil, the arable layer before installation of the experiment was neutral $\left(\mathrm{pH}_{\mathrm{KCl}^{-}}-7.0\right)$, with medium humus content $(2.18 \%)$, high phosphorous $\left(\mathrm{P}_{2} \mathrm{O}_{5}-271 \mathrm{mg} \mathrm{kg}^{-1}\right)$, and potassium content reached $173 \mathrm{mg} \mathrm{kg}^{-1}\left(\mathrm{~K}_{2} \mathrm{O}\right)$. Agrochemical parameters of the soil were determined applying accepted analytical methods: $\mathrm{pH}_{\mathrm{KCl}}$ - IS0 10390:2005 (potentiometric), contents of mobile phosphorus and potassium were estimated by Egner-Rimo-Domingo (A-L) GOST 26208-84, humus content - ISO 10694:1995 (dry burning).

Assessment of photosynthesis productivity. Assimilation area of plant leaves for five plants was estimated (WinDias leaf area measurer), fresh and dry leaf mass was measured. The photosynthesis productivity $\left(\mathrm{F}_{\mathrm{pr}}\right)$ is calculated according to the formula:

$$
F_{p r}=2\left(M_{2}-M_{1}\right) /\left(L_{1}+L_{2}\right) * T
$$

Here: $M_{2}$ and $M_{1}-$ dry matter content increase over particular time;

$L_{1}$ and $L_{2}-$ leaf surface area at the beginning and end of the period;

$T$ - length of time in days (Bluzmanas ir kt., 1991).

The content of photosynthetic pigments (chlorophyll $a, b$ and carotenoids) in fresh leaf mass was determined using 96\% ethyl alcohol using Spectrophotometric Wettstein method with spectrophotometer „Genesys 6” (Beadle et al., 1987).

Winter wheat 'Artist', 'Edvin', 'Skagen', 'Viola', and 'Bertold' were sowed on 18th of September in 2015 applying sowing-machine $A C C O R D$,, $m$-drill“. Seed rate 4.0 million units ha ${ }^{-1}$ or $180-190 \mathrm{~kg} \mathrm{ha}^{-1}$ viable seeds. Seeds of category C2 were treated with a mixture of two seed treatments - Maxim Star 025 FS (1 $\left.1 \mathrm{t} \mathrm{t}^{-1}\right)$ and Maxim $0.25 \mathrm{FS}_{(0.7} \mathrm{t} \mathrm{t}^{-}$ ${ }^{1}$ ). The yield was harvested with a small combine harvester WINTERSTEIGER DELTA (working width 2 m, computerized weighing, moisture and gravity detection system, automatic sampling available in the cabin).

Samples for photosynthetic parameters assessment were sampled: on 1st of December in 2015, on 3rd of May in 2016, on 23rd of May in 2016, on 9th of June 2016, and on 1st of July in 2016.

The data of the study were processed by the Microsoft Office Excel program. The accuracy of the data analysis was estimated applying the standard deviation from the mean.

\section{RESULTS OF THE RESEARCH}

Observation of the crop's photosynthetic parameters allows for proper selection of plant cultivation processes. Formation of the plant's net photosynthetic productivity is possible by indicating an appropriate variety, applying suitable crop density, thereby ensuring adequate light conditions and fertilizing with nitrogen fertilizers (Tarvydiene ir kt., 2004). The net photosynthetic productivity of winter wheat varied according to the growth stage in the experiment. Trends destined by genotype and meteorological conditions can be traced (Fig. 1-5). 


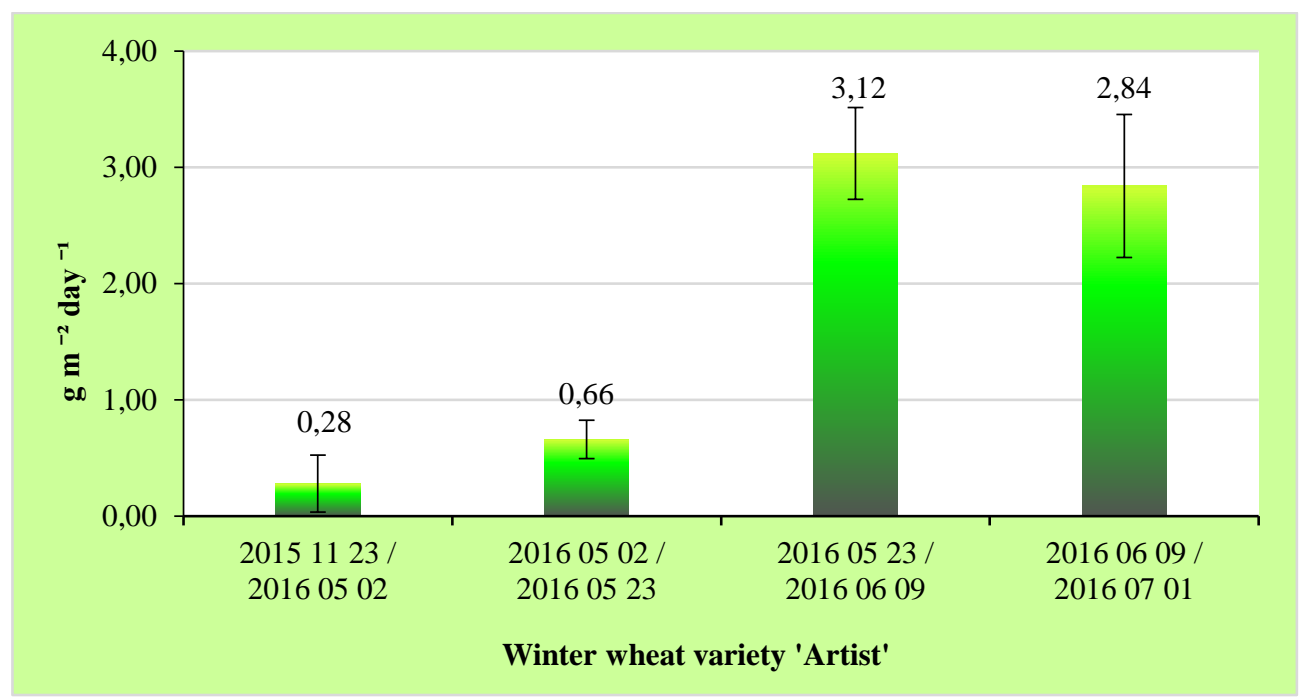

Figure 1. Photosynthesis productivity in winter wheat variety 'Artist', 2015-2016.

The winter wheat variety 'Artist' has accumulated a $0.28 \mathrm{gm}^{-2}$ day $^{-1}$ photosynthesis productivity (Fig. 1) during the time from the beginning of the autumn vegetation to the vegetation renewal in the spring.

From 2nd of May until 23rd of May, when the average temperature of the air reached $15.02^{\circ} \mathrm{C}$, the productivity increased to $0.66 \mathrm{gm}^{-2}$ day $^{-1}$. The period since $23 \mathrm{rd}$ of May to 9 th of June 2016 coincided with the winter wheat flowering stage. At that time, the photosynthesis productivity of $3.12 \mathrm{gm}^{-2} \mathrm{day}^{-1}$ was determined in the leaves of the winter wheat variety 'Artist'. Since the second decade of June to the first decade of July, photosynthesis productivity in winter wheat variety 'Artist' declined and reached the $2.84 \mathrm{gm}^{-2} \mathrm{day}^{-1}$ limit. At that time the milky ripening stage has been already started and the plants began to dry, the process of biomass accumulation slowed down. The leaves of this winter wheat variety, comparing with others, have remained green for the longest time.

Photosynthesis productivity in winter wheat early growth variety 'Edvin' until to the beginning of spring vegetation was $0.37 \mathrm{gm}^{-2} \mathrm{day}^{-1}$ (Fig. 2). The photosynthesis productivity of the winter wheat variety 'Edvin' increased by $0.56 \mathrm{gm}^{-2} \mathrm{day}^{-1}$ and reached $0.97 \mathrm{gm}^{-2} \mathrm{day}^{-1}$ from the beginning of the first decade of May to the beginning of the third decade of May in 2016.

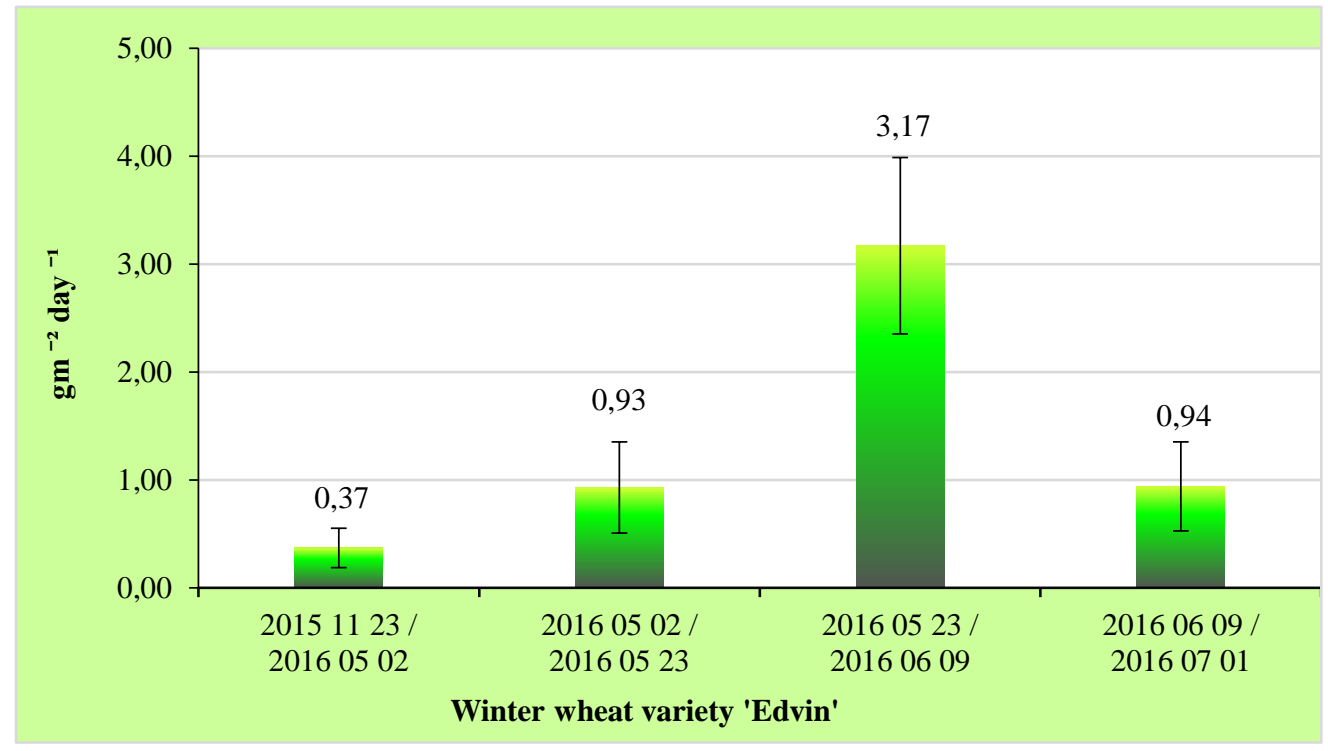

Figure 2. Photosynthesis productivity in winter wheat variety ‘Edvin’, 2015-2016.

Since 23rd of May until 9th of June in 2016, the parameter increased by $2.24 \mathrm{gm}^{-2} \mathrm{day}^{-1}$ and constituted $3.17 \mathrm{gm}^{-}$ ${ }^{2}$ day $^{-1}$ at that time. A sudden and positive increase in photosynthesis productivity increase coincided with the winter wheat flowering stage. During the period from 9th of June to 1st of July in 2016, the decrease in the net photosynthetic productivity of the winter wheat variety 'Edvin' from $3.17 \mathrm{gm}^{-2} \mathrm{day}^{-1}$ to $0.94 \mathrm{gm}^{-2} \mathrm{day}^{-1}$ was determined. At the milky ripening stage, winter wheat grains intensively accumulate organic matter, and photosynthesis productivity decreases due to increased leaf reduction.

The photosynthesis productivity in winter wheat variety 'Bertold' varied in different proportions than in varieties 'Artist' and 'Edvin' (Fig. 3). 


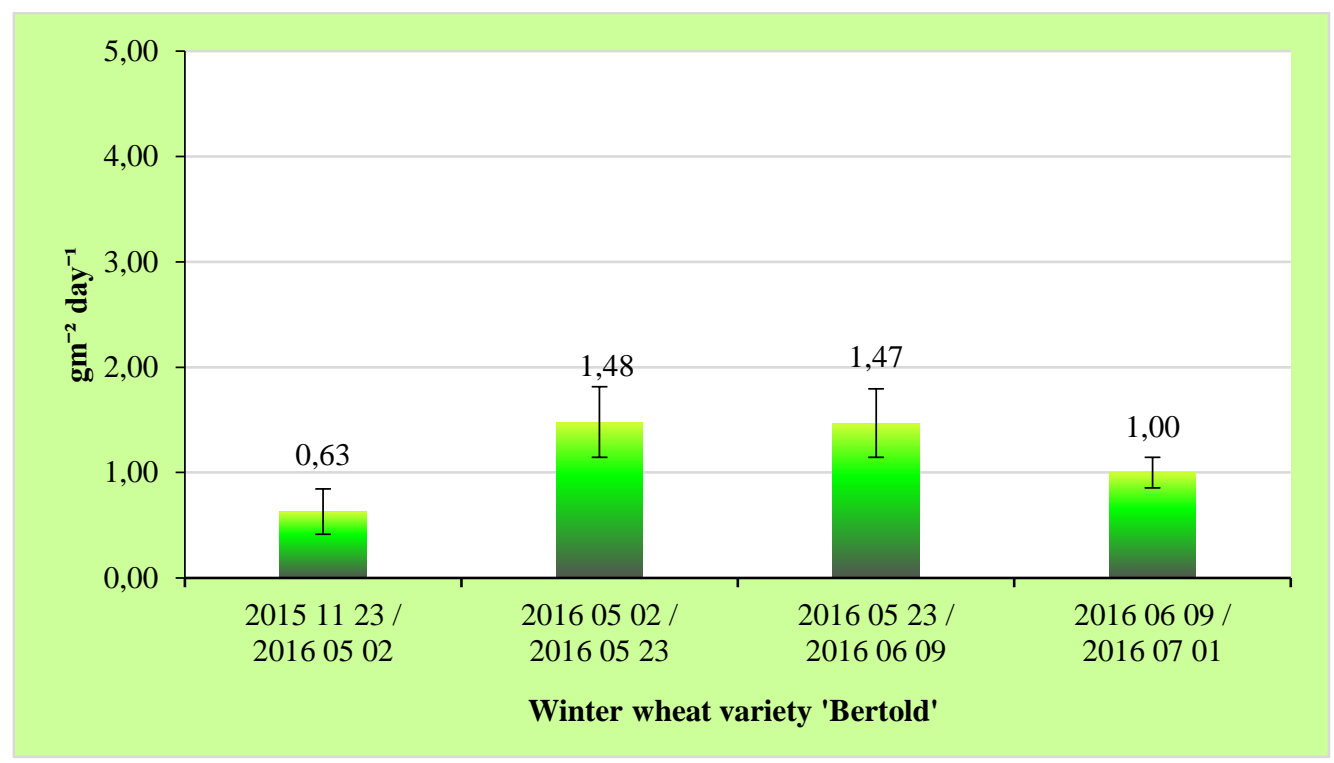

Figure 3. Photosynthesis productivity in winter wheat variety 'Bertold', 2015-2016.

Since autumn to spring vegetation renewal, the photosynthesis productivity in this variety was defined $0.63 \mathrm{gm}-2$ day $^{-1}$. From 2nd of May until 23rd of May, the variation in photosynthesis productivity of variety 'Bertold' was 0.85 gm $^{-}$ ${ }^{2}$ day $^{-1}$, which almost twice exceeded the variations in photosynthesis productivity in 'Artist' and 'Edvin' in the same period (Fig. 1-3). The photosynthesis productivity in winter wheat variety's 'Bertold' leaves decreased from $1.48 \mathrm{gm}^{-2}$ day $^{-1}$ to $1.47 \mathrm{gm}^{-2}$ day $^{-1}$ (Fig. 3) during the important for plants flowering stage, and furthermore the parameter declined to $1.00 \mathrm{gm}^{-2} \mathrm{day}^{-1}$ since 9 th of June to 1 st of July.

Winter wheat variety 'Viola' had a lower photosynthesis productivity than the other tested varieties until the flowering period of the cereals. In autumn, photosynthesis productivity of $0.37 \mathrm{gm}^{-2} \mathrm{day}^{-1}$ was determined (Fig. 4). From 2nd of May until 23rd of May, value of photosynthesis productivity has doubled. During the flowering, from 23rd of May to 9 th of June, a particularly rapid increase in photosynthesis productivity (from $0.83 \mathrm{gm}^{-2} \mathrm{day}^{-1}$ to $3.39 \mathrm{gm}^{-2} \mathrm{day}^{-1}$ ) was determined. The photosynthesis productivity dropped to $0.65 \mathrm{gm}^{-2} \mathrm{day}^{-1}$ when milky ripening stage das started, since 9 th of June to 1 st of July.

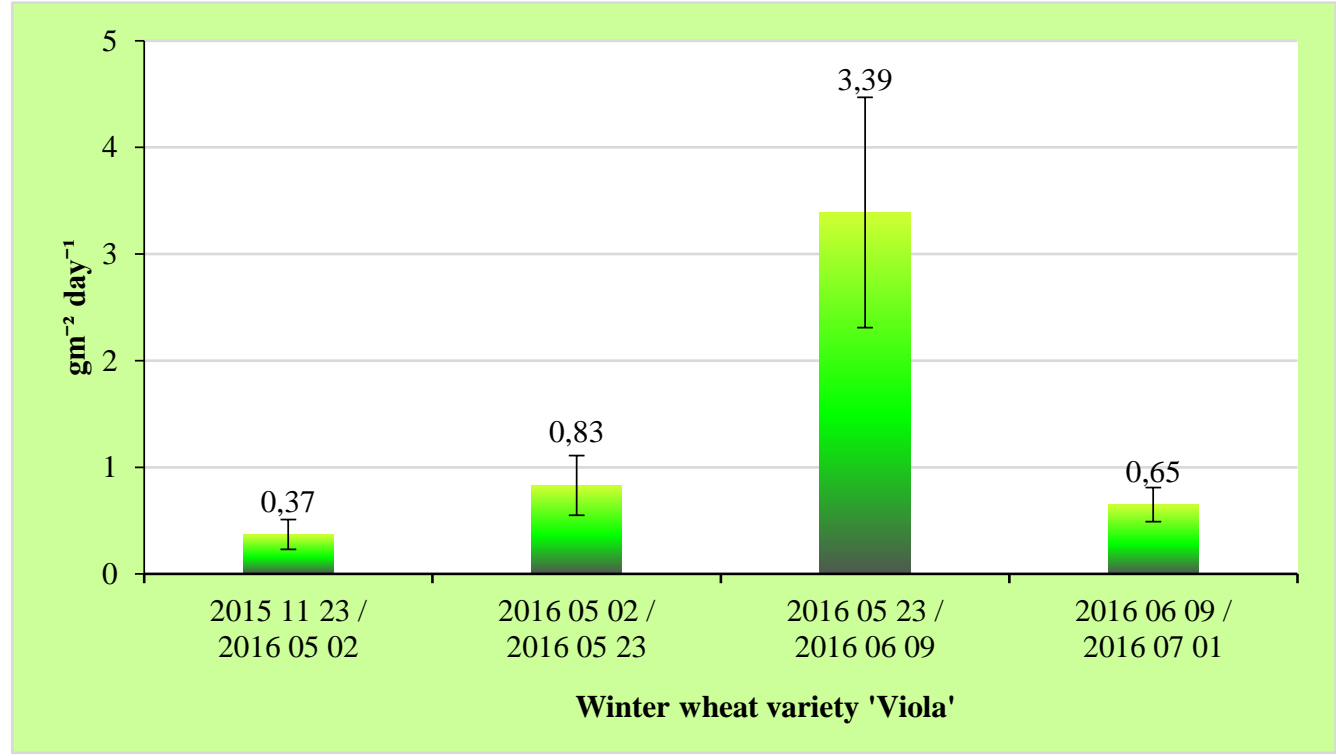

Figure 4. Photosynthesis productivity in winter wheat variety 'Viola', 2015-2016.

The lowest photosynthesis productivity $0.26 \mathrm{gm}^{-2} \mathrm{day}^{-1}$ in winter wheat variety 'Skagen' was defined in autumn (Fig. 5), however onwards during the period from 2nd of May to 23rd of May 2016, the photosynthesis productivity was higher than that of the winter wheat variety 'Viola' (Fig. 4-5). 


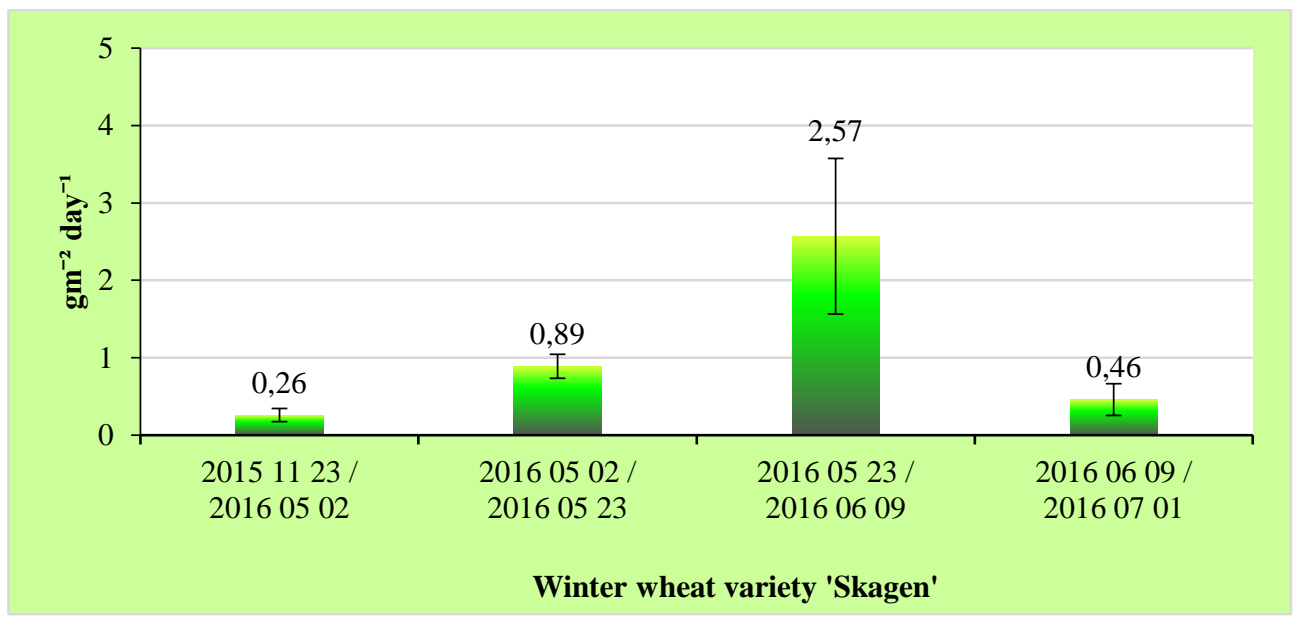

Figure 5. Photosynthesis productivity in winter wheat variety 'Skagen', 2015-2016.

During the period from 23rd of May until 9th of June 2016, the photosynthesis productivity of the variety 'Skagen' $\left(2.57 \mathrm{gm}^{-2} \mathrm{day}^{-1}\right)$ was lower than that of varieties 'Viola' and 'Edvin', however it has been observed higher than in winter wheat variety 'Bertold' (Fig. 2-5). From 9th of June until 1st of July in 2016, the photosynthesis productivity of wheat variety 'Skagen' has slowly dropped from $2.57 \mathrm{gm}^{-2}$ day ${ }^{-1}$ to $0.46 \mathrm{gm}^{-2} \mathrm{day}^{-1}$.

\section{CONCLUSIONS}

1. The highest photosynthesis productivity was determined in the leaves of the winter wheat variety 'Artist' during the jointing - booting stages $\left(3.12-2.84 \mathrm{gm}^{-2} \mathrm{day}^{-1}\right)$.

2. The lowest photosynthesis productivity was recorded in the leaves of winter wheat variety 'Bertold' (from $0.63 \mathrm{gm}^{-}$ ${ }^{2}$ day $^{-1}$ during tillering stage in autumn to $1.48 \mathrm{gm}^{-2} \mathrm{day}^{-1}$ during tillering stage in spring).

\section{REFERENCES}

1. Bluzmanas, P.; Borusas, S.; Dagys, J.; Gruodienė, J. ir kt. 1991. Plant physiology. Vilnius, p. 201. [In Lithuanian]

2. Balogh, A. Hornok, M. Pepo, P. 2007. Study of physiological parameters in sustainable winter wheat (Triticum aestivum L.) production. Cereal Research Communications, No. 35, pp. 205-208. https://doi.org/10.1556/CRC.35.2007.2.10

3. Beadle, C. I.; Coombs, J.; Hall D. O.; Long, S. P.1987. Plant growth analyses. Techniques in bioproductivity and photosynthesis. pp. 20-25.

4. Chapple, C.; Campbell, M.M. 2007. Physiology and metabolism factors impacting plant productivity. Current Opinion in Plant Biology, Vol. 10, pp. 217-219. https://doi.org/10.1016/j.pbi.2007.04.016

5. Ruzgas, V.; Liatukas, Ž. 2006. Naujausi agronomijos tyrimų rezultatai: konferencijos pranešimai Nr. 38. Resistance to diseases of winter wheat breeding material, selection of promising numbers in natural and infectious backgrounds. Dotnuva - Akademija (Kèdainių r.) pp. 59-60. [In Lithuanian]

6. Sakalauskienè, S.; Šabajevienè, G.; Lazauskas, S.; Brazaitytè, A.; Samuolienė, G.; Urbonavičiūtè, A.; Sakalauskaitè, J.; Ulinskaitè, R.; Duchovskis, P. 2008. Complex effect of different moisture and temperature regime on photosynthetic indices of radish in IIIIV stages of organogenesis. Sodininkyste ir daržininkystè, Vol. 27. Nr. 1. p. 9 -104. [In Lithuanian]

7. Scebba, F.; Soldatini, G.; Ranieri A. 2003. Ozone differentaly affects and biochemical responses two clover spieces: Trifolium repens and Trifolium oratense. Envirinmental Pollution. Vol. 123, No. p. 209-216.

8. Tarvydienė, A., Duchovskis, P., Šiuliauskas, A. 2004. Dynamics of photosynthetic indicators of red beet in differently fertilized crop. Sodininkyste ir daržininkystè, 23(3), p. 76-88. [In Lithuanian]

9. Tranavičienè, T. 2009. Effect of nitrogen on the photosynthesis of different varieties of common wheat (Triticum aestivum L.) and grain quality parameters. PhD thesis: Biomedical sciences, Agronomy. Akademija, (Kauno r.), p. 41-44. [In Lithuanian]

10. Третьяков, Н.Н. 1998. Physiology and biochemistry of agricultural plants. Физиология и биохимия сельскохозяйственных растений. - Москва, с.639. [In Russian] 